\title{
Feasibilities of the Pinhole Surgical Technique: Mini Review
}

\author{
Saad Al-Almaie* \\ Consultant Prosthodontist and Oral Implantologist, KFMMC, Saudi Arabia
}

Submission: March 07, 2017; Published: April 07, 2017

*Corresponding author: Saad Al-Almaie, Consultant Prosthodontist and Oral Implantologist, Medical Administration, Tel: +966504805413;

Fax: +966-3-8440000; Email: stsralmaie@yahoo.com

Abstract

The concept and technique of the pinhole surgical procedures has been a debated topic in dentistry in recent years. This paper consists of a mini review of the literature available on pinhole surgical technique. This review shows that pinhole surgical technique allows us to reposition the gums quickly and easily, with the less invasive method, a decreased patient discomfort, a shorter treatment and recovery time and much less pain.

Keywords: Pinhole surgical technique; Minimally invasive surgery; Recession

\section{Introduction}

Gum recession refers to the loss of gum tissue along the gum line. This can occur as a result of periodontal disease (gingivitis, periodontitis, advanced periodontitis), the natural aging process, or abrasive habits when it comes to brushing the teeth. When gum recession occurs, the root structure of the tooth becomes exposed and loses of the tissues covering the root. This means that tooth decay and other problems can affect the teeth along the gum line and beneath it. Since healthy gums are essential for a healthy mouth, getting gum recession treated is important for lasting dental wellness [1-3]. The surgeons are now interested in more user-friendly, less invasive, esthetically favorable patient oriented surgeries as they now aim at/prioritize patient comfort, satisfaction, and patient centered outcomes. The concept of "extension for prevention" has now changed to "conserve to preserve." The concept of "minimally invasive surgery (MIS)" is one such peculiar and innovative approach which aims to produce minimal wounds, minimal flap reflection, and gentle handling of the soft and hard tissues [4]. Wickham and Filtz described the techniques of using smaller incisions as "MIS" which were later defined by medical subject headings as those procedures that avoid the use of open invasive surgery in favor of closed or local surgery. Hunter and Sackier described the same as "the ability to miniaturize our eyes and extend our hands to perform microscopic and macroscopic operations in places that could previously be reached only by large incisions [5]." In recent years a novel surgical approach to root coverage, called the pinhole surgical technique, has been gaining exposure. Chao introduced it for Miller class I, II, and III recession defects and reported favorable predictability for root coverage and defect reduction up to 18 months following the procedure [6]. Miller introduced his classification system [7]. The author related the extent of the soft tissue recession to the location of the mucogingival junction as well as the height of interproximal clinical attachment adjacent to the surface affected by the recession.

\section{Review of Literature}

Pub Med databases were used to search for published articles about pinhole surgical technique. Clinical studies and cases using this technique were included. Letters to the Editor, historical reviews, and unpublished articles were not sought. Some articles were directly excluded after reading only their titles. At this stage there were 9 to 10 articles included, and the inclusion and exclusion criteria were defined. Thirteen articles were included for full-text reading. After reading these, three more articles were excluded, as they did not fulfill the inclusion criteria. These articles were included in introduction and discussion in addition to that, more reviews of literature had been included regarding pinhole surgical technique.

\section{Main Outcomes of Selected Studies}

This treatment offers a more conservative alternative to common periodontal treatments, such as gum grafting. With the Pinhole Surgical Technique, the clinician makes a small hole in the gums, the size of a needlepoint, and then manipulates the tissue to correct recession and other issues. In addition, for some cases, a biocompatible collagen agent is inserted, filling the space between gingival tissue and the roots, which helps heal the area and allow healthy tissue to attach to the teeth. Most of the 
selected studies considered different benefits, including cosmetic improvement, arresting further breakdown, no need for scalpels or sutures, preservation of natural gum tissue, and reduced risk of periodontal problems [6,8-13].

\section{Discussion}

Zucchelli and Sanctis conducted a case series study to evaluate root coverage with a new surgical approach to the coronally advanced flap procedure for treatment of multiple recession defects in patients with esthetic demands at 1 year examination. The results showed $88 \%$ complete root coverage and greater reductions in recession in cases with less amount of keratinized tissue apical to recession defect [8]. In 2005 zucchelli et al. [9] conducted a long term case series (5 years) for treatment of Multiple Adjacent Recession Defects (MRTD) using envelope type coronally advanced flap and the 5 year follow up showed, increased in keratinized tissue and $85 \%$ of treated recessions defects showed complete root coverage. Chambrone et al. [10] conducted a systematic review of periodontal plastic surgery in the treatment of multiple recession type defects and concluded that the mean width of keratinized tissue increased significantly and mean root coverage achieved ranged from $94 \%$ - 98\% and the need for more randomized controlled trials to identify the indication for each surgical technique. A split mouth study randomized controlled was conducted by pini prato et al. [11] in 2010 to evaluate coronally advanced flap versus connective tissue graft in the treatment of multiple gingival recessions with a 5 year follow up and concluded that $52 \%$ sites showed completed root coverage when treated with coronally advanced flap and connective tissue graft in comparison to $35 \%$ coverage in coronally advanced flap treated sites. A new minimally invasive treatment of multiple gingival recession defects in maxillary anterior region was achieved by zadeh [12] as a case series by vestibular incision subperiosteal tunnel access technique. The result showed good outcome in esthetic zones.

A randomized controlled trial for treatment of multiple recession defects was conducted by ozcelik et al. [13] using coronally advanced flap combined with orthodontic button application and the result showed $84 \%$ complete root coverage and high patient satisfaction with esthetic demands. A novel approach for treatment of multiple recession defects using a Pin Hole Surgical Technique was introduced by John Chao [6]. The Author concluded that $94 \%$ mean defect reduction was obtained along with minimum post-operative complications and optimal patient based outcome. The Chao Pinhole Surgical Technique (PST) is a minimally invasive option for treating gum recession. Unlike traditional grafting techniques, PST is incision and suture free. Traditional gum recession treatments involve the use of donor tissue or soft tissue grafts in order to rebuild the gum line. This soft tissue would be sutured in place and would join with existing gum tissue as it healed. During the Chao Pinhole Surgical Technique, a needle is used to make a small hole in the patient's existing gum tissue. Through this pinhole, special instruments are used to gently loosen the gum tissue. These tools help expand and slide the gum line to cover the exposed root structure. There are no grafts, no sutures, and no incisions needed with the Chao Pinhole Surgical Technique. It simply involves the adjustment of the existing tissue.

Chao conducted different benefits of the Pinhole Surgical Technique

a. Less discomfort for the patient after treatment.

b. Faster recovery for the patient than traditional grafting.

c. No need for scalpels or invasive surgical tools.

d. No need to take donor tissue from the patient's palate.

e. Excellent, natural-looking, long-lasting results.

The Pinhole Surgical Technique, is an incision-free, suturefree procedure for treating gum recession. Through a small pinhole made by a needle and uses specially designed instruments to gently loosen the gum tissue and glide it over the receded part of the tooth. Since there is no incision or suturing, patients can expect minimal post-operative symptoms (pain, swelling and bleeding) [6].

\section{Conclusion}

Pinhole surgical technique is one such novel technique which holds promise as a minimally invasive, predictable, efficient, time and cost-effective procedure for recession coverage in Millers Class I and Class II recession defects mainly occur in buccal areas and the main etiologic factors include trauma from tooth brushing, malposition of teeth, ectopic insertion of frenum and muscle attachment. There is a need for more long term research to be carried out to analyze the success of pinhole surgical technique in management of single or multiple recession defects.

\section{Conflict of Interest}

No conflict of interest was exists.

\section{References}

1. (2001) Glossary of Periodontal Terms. ( $4^{\text {th }}$ edn), American Academy of Periodontology, Chicago, USA, pp. 53-56.

2. Lawrence HP, Hunt RJ, Beck JP (1995) Three Year root caries incidence and risk modelling in older adults in North Carolina. J Public Health Dent 55(2): 69-78.

3. Carvalho P, Da Silva RC, Cury P (2006) Modified coronally advanced flap associated with a subepithelial connective tissue graft for treatment of adjacent multiple recessions. J Periodontol 77(11): 19011906.

4. Banthia R, Dongre M, Ritika R, Banthia P (2016) Minimally invasive techniques for regenerative therapy. J Interdiscip Dentistry 6(1): 5659.

5. Dannan A (2011) Minimally invasive periodontal therapy. J Indian Soc Periodontol 15(4): 338-343.

6. Chao J (2012) A novel approach to root coverage: Pinhole surgical technique. Int J Periodontics Restorative Dent 32(5): 521-531.

7. Miller PD (1985) A classification of marginal tissue recession. Int J Periodontics Restorative Dent 5(2): 8-13. 
8. Zucchelli G, Sanctis M (2000) Treatment of multiple adjacent recession defects in patients with esthetic demands. J Periodontol 71(9): 15061514.

9. Zucchelli G, De Sanctis M (2005) Long term outcome following treatment of multiple Miller Class I and II recession defects in esthetic areas of mouth. J Periodontol 76(12): 2286-2292.

10. Chambrone L, Lima LA, Pustiglione FE, Chambrone LA (2009) Systematic review of perio-plastic surgery in the treatment of multiple recessions type defects. J Can Dent Assoc 75(3): 203a-203f.

11. Pini Prato GP, Cairo F, Nieri M, Franceschi D, Rotundo R, et al. (2010) Coronally advanced flap versus connective tissue graft in treatment of multiple gingival recessions: a split mouth study with 5year follow up. J Clin Periodontol 37(7): 644-650.

12. Zadeh HH (2011) Minimally invasive treatment of maxillary anterior gingival recession defects by vestibular incision subperiosteal tunnel access and platelet derived growth factor BB. Int J Periodontics Restotative 31(6): 653-660.

13. Ozcelik 0, Haytac MC, Seydaoglu G (2011) Treatment of multiple gingival recession using a coronally advanced flap procedure combined with button application. J Clin Periodontol 38(6): 572-580.

\section{Your next submission with Juniper Publishers will reach you the below assets}

- Quality Editorial service

- Swift Peer Review

- Reprints availability

- E-prints Service

- Manuscript Podcast for convenient understanding

- Global attainment for your research

- Manuscript accessibility in different formats

( Pdf, E-pub, Full Text, Audio)

- Unceasing customer service

Track the below URL for one-step submission https://juniperpublishers.com/online-submission.php 